\title{
Neonates with Jaundice A Clinical Profile
}

\author{
Davis Manuel', Shajahan R A \\ ${ }^{1}$ Associate Professor, Department of Paediatrics, P K Das Institute of Medical Sciences, Vaniyamkulam, Ottapalam, Palakkad, Kerala-679522, ${ }^{2}$ Assistant Professor, \\ Department of Paediatrics, P K Das Institute of Medical Sciences, Vaniyamkulam, Ottapalam, Palakkad, Kerala-679522.
}

\section{Abstract}

Background: In the first week of child birth, neonatal jaundice is the most common problem which leads to delayed hospital discharge and readmissions. Recognising early neonatal hyperbilirubenemia plays a pivotal role in preventing serious complications. The aim of this study was to study the clinical profile and the aetiological factors leading to neonatal jaundice in rural areas. Subject and Method: This study is a prospective observational study conducted in neonatal intensive care unit (NICU) and post natal ward . This study was conducted during the period of February 2017 to July 2017. Total 400 neonates were admitted in NICU and post natal ward during this period. Out of them, 100 newborns were having jaundice (Serum bilirubin $>10 \mathrm{mg} / \mathrm{dl}$ ). 100 cases in total were enrolled in the study. Result: In this study, out of 100 neonates, $70 \%$ were males and 30\% were females. , 92 were born at term (92\%) and remaining 10 were preterm babies (10\%). Physiological jaundice constituted $45 \%$, followed by ABO incompatibility constituted $25 \%$, followed by sepsis(1\%), Rh incompatibility ( $8 \%$ ), idioapathy $(8 \%)$, prematurity $(5 \%)$, cephalhematoma $(4 \%)$, breast feeding $(2 \%)$, haemolytic anemia $(2 \%)$ were diagnosed as hereditary spherocytosis. Conclusion: Physiological jaundice is the most common cause of neonatal jaundice followed by ABO incompatibility, sepsis, Rh incompatibility and idiopathic cases. Cephalhematoma, breast feeding jaundice and haemolytic anaemia are the less common causes. Hence, it is required to monitor neonates more appropriately and accurately.

Keywords: Physiological Jaundice, Rh incompatibility.

Corresponding Author: Dr. Shajahan R A, Assistant Professor, Department of Paediatrics, P K Das Institute of Medical Sciences , Vaniyamkulam, Ottapalam, Palakkad, Kerala-679522.

Email: drsujathapasula@gmail.com

Received: January 2020

Accepted: January 2020

\section{Introduction}

In first week after child birth, Jaundice is the most common problem. $60 \%$ of full term infants have jaundice and $80 \%$ of preterm babies have jaundice in the first week. ${ }^{[1]}$ For delayed hospital discharge and re-admissions in the first week of life, jaundice is the commonest reason. Severe neonatal jaundice has the potential to cause bilirubin encephalopathy which can further increase to permanent and chronic neurologic sequelae. Survivors suffer from severe neurological handicaps, such as cerebral palsy, gaze palsies and deafness. ${ }^{[2,3]}$ Sequela is not reversible but it is prevented by early diagnosis and appropriate neonatal jaundice management. Identification of etiological and risk factors is of utmost importance for the management of neonatal jaundice. The neonatal jaundice's incidence, etiological and contributory factors vary according to ethnic and geographic differences. ${ }^{[4]}$ As a result of racial, cultural and environmental differences, in developing countries, these factors may be different from those of developed nations. To identify additional risk factors that may be particular, the need for more robust epidemiological studies in low and middle income studies was highlighted. ${ }^{[5]}$ The aim of this study was to study the clinical profile and the aetiological factors leading to neonatal jaundice in rural areas. Subjects and Methods

This This study is a prospective observational study conducted in neonatal intensive care unit (NICU) and post natal ward. This study was conducted during the period of February 2017 to July 2017. Total 400 neonates were admitted in NICU and post natal ward during this period. Out of them, 100 newborns were having jaundice (Serum bilirubin $>10 \mathrm{mg} / \mathrm{dl}$ ). 100 cases in total were enrolled in the study. Babies attending outpatient department were excluded from study. By clinical methods, jaundice was determined and biochemical tests confirmed this. Van der Bergh method was used to estimate serum bilirubin. Inclusion criteria was that all babies with serum bilirubin value of greater than $10 \mathrm{mg} / \mathrm{dl}$. Detailed history was obtained, physical examinations and other relevant examinations were carried out. Age, birth weight, age of jaundice detection, breast feeding status, family status of jaundice was documented. On babies who were having physiological jaundice, investigations were not carried out. For baby and mother, blood grouping and Rh typing were done. For Rh incompatibility, cord blood bilirubin, haemoglobin, direct coombs test and bilirubin monitoring 


\section{Manuel d Shajahan; Neanates with Jaundice A Clinical Profile}

was done. Other investigations like haemoglobin level, peripheral smear and reticulocyte count were done. By using fluorescent technique, G6PD was done. For sickling test, 2\% metabisulphite was used. Using serial dilutions of sodium chloride, osmotic fragility test was performed. Neonates suspected to have sepsis were investigated by complete blood count, septic screen and blood and urine cultutes. In all neonates, thyroid function tests were carried out. Informed consent was obtained from parents of all babies. Statistical data was analysed. Percentages and ratios were calculated.

\section{Results}

Results were expressed as percentages and ratios. Out of 100 neonates, $70 \%$ were males and $30 \%$ were females.

Table 1: Distribution according to gestational age
\begin{tabular}{|l|l|l|}
\hline Gestational Age (Weeks) & Number & Percentage \\
\hline$\geq 37$ & 92 & 92 \\
\hline $34-36$ & 7 & 7 \\
\hline $30-34$ & 1 & 1 \\
\hline Total & 100 & 100 \\
\hline
\end{tabular}

Table 1 shows that out of 100 jaundiced neonates, 92 were born at term $(92 \%)$ and remaining 10 were preterm babies $(10 \%)$.

\section{Table 2: Distribution based on birth weight}

\begin{tabular}{|l|l|l|}
\hline Birth Weight (Grams) & Number & Percentage \\
\hline $1000-1500$ & 1 & 1 \\
\hline $1501-2000$ & 5 & 5 \\
\hline $2001-2500$ & 8 & 8 \\
\hline $2501-3000$ & 60 & 60 \\
\hline$>3000$ & 26 & 26 \\
\hline Total & 100 & 100 \\
\hline
\end{tabular}

Table 2 shows that among 100 neonates, majority of the babies had birth weight between 2501-3000 grams (60\%), 14 babies had birth weight less than 2500 grams (14\%).

\begin{tabular}{|c|c|c|}
\hline Aetiology & Number & Percentage \\
\hline Physiological Jaundice & 45 & 45 \\
\hline $\mathrm{ABO}$ incompatibility & 25 & 25 \\
\hline Sepsis & 1 & 1 \\
\hline Rh incompatibility & 8 & 8 \\
\hline Idiopathy & 8 & 8 \\
\hline Prematurity & 5 & 5 \\
\hline Cephalhematoma & 4 & 4 \\
\hline Breast feeding & 2 & 2 \\
\hline Haemolytic Anaemia & 2 & 2 \\
\hline G6PD deficiency & 0 & 0 \\
\hline Hypothyroidism & 0 & 0 \\
\hline
\end{tabular}

Table 3 shows that physiological constituted $45 \%$, followed by $\mathrm{ABO}$ incompatibility constituted $25 \%$, followed by sepsis(1\%), $\mathrm{Rh}$ incompatibility (8\%), idioapathy (8\%), prematurity $(5 \%)$, cephalhematoma $(4 \%)$, breast feeding
( $2 \%)$, haemolytic anemia $(2 \%)$ were diagnosed as hereditary spherocytosis.

\section{Discussion}

Majority of babies with neonatal jaundice were of term gestation in the present study. Only $10 \%$ were preterm babies. A higher percentage of premature babies were seen in Bhutani et al study. ${ }^{[6]}$ The higher percentage of term babies is because of low to moderate risk pregnancies and hence majority of the babies were of term or near term gestation in our study. In our study, out of 100 patients, $70 \%$ were males and $30 \%$ were females. Similar results were observed in Narang et $\mathrm{al}^{[7]}$, Effiong et $\mathrm{al}^{[8]}$ and Korejo et $\mathrm{al}^{[9]}$ studies in which majority of babies were males. Among 100 neonates, majority of the babies had birth weight between 2501-3000 grams (60\%), 14 babies had birth weight less than 2500 grams (14\%).In the present study, physiological jaundice was observed in majority of babies (45 out of 100 babies). This is similar to previous studies. In Bahl et $\mathrm{al}^{[10]}$ study, the physiological jaundice contributed majority of patients $(63.8 \%)$ studied. High incidence of physiological jaundice was also observed in Singhal et al ${ }^{[11]}$ $(16.7 \%)$ and Merchant et $\mathrm{al}^{[12]}(25.3 \%)$. This was followed by $\mathrm{ABO}$ incompatibility which constituted $25 \%$ as the next leading cause for neonatal jaundice. Similar findings were observed in studies of Verma et $\mathrm{al}^{[13]}$ and Merchant et $\mathrm{al}^{[12]}$ $(22.6 \%)$. In Bahl et $\mathrm{al}^{[10]}$ study, higher incidence of $\mathrm{OA}$ incompatibility was observed $(60 \%)$ where as in Bajpai PC et $\mathrm{a}^{[14]}$ study, a higher incidence of $\mathrm{OB}$ incompatibility was observed. In present study, the number of $\mathrm{OA}$ and $\mathrm{OB}$ incompatibility was equal. Sepsis contributed $1 \%$ in the present study. In Merchant et al ${ }^{[12]}$ study, $8 \%$ of the neonates had sepsis, $11.6 \%$ in Verma et al ${ }^{[13]}$ study and $9.6 \%$ was observed in Narang et $\mathrm{al}^{[7]}$ study. $\mathrm{Rh}$ incompatibility was observed in $8 \%$ of the patients, in Bajpai PC et al ${ }^{[14]}$ study, $1.6 \%$ of the patients had $\mathrm{Rh}$ incompatibility. In Verma et $\mathrm{al}^{[13]}$ study, it was observed in $9.8 \%$ of cases. In Singhal et $\mathrm{al}^{[11]}$ study, it was present in $8.1 \%$ of neonates. Idioapathy $(8 \%)$, prematurity $(5 \%)$ was observed in the present study. cephalhematoma $(4 \%)$ was present in our study whereas in Narang et $\mathrm{al}^{[7]}$ study, $6.3 \%$ incidence was observed. Breast feeding $(2 \%)$, haemolytic anemia $(2 \%)$ were observed in the present study. G6PD deficiency was reported in $2.6 \%$ neonates by Merchant et $\mathrm{al}^{[12]}$ and $3.4 \%$ by Narang et $\mathrm{al}^{[7]}$, where as in our study, no case of G6PD was observed. In study conducted by Shemeena Valiyat et $\mathrm{al}^{[15]}$ out of 110 jaundiced neonates, $102(92.5 \%)$ were term babies and 8 $(7.3 \%)$ were preterm, $69(62.75 \%)$ were males and 41 $(37.27 \%)$ females. Physiological jaundice was seen in 44 $(40 \%)$ of neonates. Various other aetiologies were ABO incompatibility 24 (21.8\%), sepsis 11 (10\%), Rh incompatibility $9(8 \%)$, idiopathic $9(8 \%)$, prematurity 8 $(7.3 \%)$, cephalhematoma $7(6.4 \%)$, breast feeding jaundice 7 $(6.4 \%)$ and haemolytic anaemia $1(0.9 \%)$. 


\section{Manuel d Shajahan; Neanates with Jaundice A Clinical Profile}

\section{Conclusion}

It can be concluded that physiological jaundice is the most common cause of neonatal jaundice followed by $\mathrm{ABO}$ incompatibility, sepsis, Rh incompatibility and idiopathic cases. Cephalhematoma, breast feeding jaundice and haemolytic anaemia are the less common causes. In identifying the neonatal group who require intensive monitoring and timely management, understanding the aetiology and risk factors for neonatal jaundice is of a priority.

\section{References}

1. Barbara JS, Kliegman RM. Jaundice and hyperbilirubinemia in the newborn. In: Kliegman RM, Behrman HB, Jenson HB, editors. Nelson textbook of paediatrics, 17th ed. Philadelphia: Elsevier Saunders. 2004:592-8.

2. Bhutani VK, Zipursky A, Blencowe H, Khanna R, Sgro M, Ebbesen $F$, et al. Neonatal hyperbilirubinemia and Rhesus disease of the newborn: incidence and impairment estimates for 2010 at regional and global levels. Pediatr Res. 2013;74(1):86-100.

3. Mwaniki MK, Atieno M, Lawn JE, Newton CRJC.Longtermneurodevelopmental outcomes after intrauterine and neonatal insults: A Systematic review. Lancet. 2012;379:445-52.

4. Ipek IO, Bozayakut A Clinically significant neonatal hyperbilirubinemia: an analysis of 546 cases in Istanbul. J. Trop. Pediatr. 2008. 54:212-3.

5. Olusanya BO, Osibanjo FB, Slusher TM. Risk factors for severe neonatal hyperbilirubinemia in low and middle-income countries: a systematic review and Meta-analysis. PLoS One. 2015;10.
6. Bhutani VK. Evidence based issues regarding neonatal hyperbilirubinemia. Paediatrics review 2005;114:130-53.

7. Narang A, Ghatwala G, Kumar P. Neonatal jaundice, an analysis of 551 cases. Indian paediatrics. 1996;34:429-32.

8. Effiong CE. Neonatal jaundice in Ibadan. Incidence and etiologic factors born in hospital, Nigeria. Journal of National Medical Association 1975;67(3):208-10.

9. Korejo H. Risk factors for kernicterus in neonatal jaundice, Karachi, Pakistan. GJMS. 2010;8:1

10. Bahl L, Sharma R, Sharma J.Aetiology of neonatal jaundice at Shimla. Indian paediatrics. 1994;31:1275-8.

11. Singhal PK, Singh M, Paul VK, Deorari AK, Ghorpade MG. Spectrum of neonatal hyperbilirubinemia: An analysis of 454 cases.Indian Pediatr 1992;29:319-25.

12. Merchant RH, Merchant SM, Babar ST. A study of 75 cases of neonatal jaundice. Indian Pediatr. 1975,12:889-93.

13. Manorama V, Chatwal J, Singh D. Neonatal hyperbilirubinemia, Indian J Paediatr. 1988;55:899-904.

14. Bajpai PC, Mishra PK, Agarwal M. An aetiological study of neonatal hyperbilirbinemia. Indian J Pediatr. 1971; 38:424-9.

15. Shemeena Valiyat, Harsha T Valoor, Sayujya Radhamadhavan, Salina Sasi Vayalil; Aetiological factors and clinical profile of neonatal jaundice from a rural area of North Kerala, India; International Journal of Contemporary Pediatrics; 2017 Jul;4(4):1169-1172.

Copyright: (C) the author(s), 2020. It is an open-access article distributed under the terms of the Creative Commons Attribution License (CC BY 4.0), which permits authors to retain ownership of the copyright for their content, and allow anyone to download, reuse, reprint, modify, distribute and/or copy the content as long as the original authors and source are cited.

How to cite this article: Manuel D, Shajahan RA. Neonates with Jaundice A Clinical Profile . Asian J. Clin. Pediatr. Neonatol.2020;8(1):2123.

DOI: dx.doi.org/10.47009/ajcpn.2020.8.1.5

Source of Support: Nil, Conflict of Interest: None declared. 